\title{
NEW QUATERNARY TEIID (LEPIDOSAURIA, SQUAMATA) LIZARD REMAINS FROM GRUTA DO URSO, TOCANTINS, BRAZIL
}

\author{
ANNIE SCHMALTZ HSIOU \\ Departamento de Biologia, FFCLRP, Universidade de São Paulo, Av. Bandeirantes 3900, 14040901, Ribeirão Preto, SP, Brazil. \\ anniehsiou@ffclrp.usp.br
}

BLAINE W. SCHUBERT

Don Sundquist Center of Excellence in Paleontology and Department of Geosciences, East Tennessee State University, Box 70636, 37614-1709, Johnson City, TN, United States. schubert@etsu.edu

\section{GISELE R. WINCK}

Laboratório de Ecologia de Vertebrados, Departamento de Ecologia, Instituto de Biologia Roberto de Alcântara Gomes, Universidade do Estado do Rio de Janeiro, Rua São Francisco Xavier 524, Pavilhão Haroldo Lisboa, sala 220, 20550-013, Rio de Janeiro, RJ, Brazil.gwinck@gmail.com

\section{SILVIO YUJI ONARY-ALVES}

Programa de Pós-Graduação em Biologia Comparada, FFCLRP, Universidade de São Paulo, Av. Bandeirantes 3900, 14040901, Ribeirão Preto, SP, Brazil.silvioyuji@gmail.com

\section{LEONARDO S. AVILLA}

Departamento de Zoologia, Laboratório de Mastozoologia, Universidade Federal do Estado do Rio de Janeiro, Av. Pasteur 458, sala 501, 22290240, Rio de Janeiro, RJ, Brazil.leonardo.avilla@gmail.com

\begin{abstract}
Here we present teiid lizard fossils from Gruta do Urso, Aurora do Tocantins, Tocantins State, northern Brazil. We describe a left lower jaw of a "Cnemidophorinae" indet. and a right dentary attributed to Tupinambis sp. These materials share with extant Teiidae a heterodont dentition with subpleurodont tooth implantation, and are assigned to Teiinae and Tupinambinae based on dental characteristics. The paleofaunal assemblage from Gruta do Urso suggests a late Pleistocene/ early Holocene age. These records add to our knowledge of the Quaternary fauna of northern Brazil.
\end{abstract}

Key words: Teiidae, lizards, Quaternary, caves, Northern Brazil.

RESUMO - Neste trabalho apresentamos restos fósseis de lagartos teídeos provenientes da Gruta do Urso, Aurora do Tocantins, Estado do Tocantins, norte do Brasil. Descrevem-se aqui uma mandíbula esquerda atribuída a um "Cnemidophorinae" indet.; e um dentário direito atribuído a Tupinambis sp. Estes materiais compartilham com os Teiidae uma dentição heterodonte exibindo uma implantação dentária subpleurodonte, sendo estes fósseis atribuídos aos Teiinae e Tupibaminae, respectivamente, devido ao padrão da morfologia dentária observada nestes dois grupo de lagartos. A assembleia paleofaunística da Gruta do Urso sugere uma idade do Neopleistoceno/Eoholoceno. Estes registros contribuem com o conhecimento da fauna Quaternária da região do Norte do Brasil.

Palavras-chave: Teiidae, lagartos, Quaternário, cavernas, norte do Brasil.

\section{INTRODUCTION}

Extant teiid lizards are widely distributed in the New World, with species occurring in South America, Central America, the West Indies, and a single extant genus restricted to North America (Savage, 1966; Presch, 1974a, 1980; Estes, 1983; Krause, 1985; Pough et al., 1998). Traditionally, teiids belong to the clade Teioidea, which is divided into two lineages: Teiinae ("Ameiva", Aspidoscelis, "Cnemidophorus", Dicrodon, Kentropyx, and Teius), and Tupinambinae (Callopistes, Crocodilurus, Dracaena and Tupinambis)
(Presch, 1974a, 1983; Estes et al., 1988; Nydam \& Cifelli, 2002; Reeder et al., 2002; Nydam et al., 2007). Some phylogenetic studies demonstrate that the interrelationships of these taxa do not support the Teiinae-Tupinambinae grouping (Moro \& Abdala, 2000; Abdala \& Moro, 2003). However, the monophyly of Teioidea is well supported mainly by morphological data, including these two subfamilies (Estes et al., 1988; Nydam \& Cifelli, 2002; Nydam et al., 2007; Conrad, 2008; Gauthier et al., 2012; Venczel \& Codrea, 2015; Simões et al., 2016). Additionally, several neontological analyses of external, hemipenial, integumental, tongue 
morphology, as well molecular, and sperm ultrastructural data, also corroborate the monophyly of the Teiinae-Tupinambinae (Teixeira, 2003; Giugliano et al., 2007).

The phylogenetic analysis performed by Nydam et al. (2007) placed Borioteiioidea, which comprises the fossil taxa from the Cretaceous of Asia and North America (including the "Polyglyphanodontinae" sensu Estes, 1983), nested highly within Teioidea (Estes et al., 1988; Nydam et al., 2007). Other phylogenetic hypotheses do not support this close relationship between borioteiioids/polyglyphanodonts and teiids, like the analysis of Conrad (2008) that placed "Polyglyphanodontidae" (sensu Conrad, 2008) paraphyletic to the dichotomy Teiinae + Tupinambinae, and the hypothesis of Gauthier et al. (2012) that separated Teioidea from "Polyglyphanodontia" (sensu Gauthier et al., 2012), placing the latter in a stem to Scleroglossa. More recent research does not support the close position of the polyglyphanodonts with Teioidea either (Venczel \& Codrea, 2015; Simões et al., 2016), reinforcing the problematic position of this extinct taxon (Simões et al., 2016). Despite this, the phylogenetic hypothesis of Venczel \& Codrea (2015), recover within Teioidea other Cretaceous fossil taxa into Teiidae. Nonosteological phylogenetic analyses (e.g. molecular and neontological approach) otherwise, offer different hypotheses of relationships among Teioidea, even suggesting the paraphyly of the family "Teioidea" and the genus Tupinambis (Harvey et al., 2012; Goicoechea et al., 2016).

South American Teiidae fossils are known since the Paleogene (Brizuela \& Albino, 2015) but mainly represented by Cenozoic records in the Miocene (Estes, 1983; Sullivan \& Estes, 1997; Albino et al., 2006, 2013; Brizuela \& Albino, 2004, 2008a,b; Pujos et al., 2009; Hsiou et al., 2009); Pliocene (Albino et al., 2009; Brizuela \& Albino, 2012a,b); and Quaternary (Albino, 1996, 2001, 2005; Albino et al., 2006; Hsiou, 2007; Camolez \& Zaher, 2010; Hsiou et al., 2012; Ferreira et al., 2012). The late Pleistocene Brazilian record is represented by three Neotropical genera ("Ameiva", "Cnemidophorus", and Tupinambis), mainly documented in the states of Rio Grande do Sul (southern Brazil), Bahia (northeastern Brazil), Goiás, Mato Grosso (central Brazil), and Minas Gerais (southeastern Brazil) (Hsiou, 2007, 2012; Camolez \& Zaher, 2010; Ferreira et al., 2012). However, many records have not been formally studied and described (Lund, 1840; Paula-Couto, 1978; Barros-Barreto et al., 1982; Guérin, 1991; Guérin et al., 1993; Faure et al., 1999) and their taxonomic status remains unclear (Hsiou et al., 2012). Here we describe new records of teiid lizards from Gruta do Urso, Aurora do Tocantins, State of Tocantins, northern Brazil (Figure 1) and discuss some aspects of the paleoenvironmental settings interpreted for the region.

\section{MATERIAL AND METHODS}

The specimens are housed at Universidade Federal do Estado do Rio de Janeiro, State of Rio de Janeiro, Brazil (UNIRIO) fossil collection, and are represented by a complete left lower jaw (UNIRIO-NM 0002) and a fragmented right dentary (UNIRIO-NM 0003). Osteological nomenclature follows Presch (1974b), Estes (1983), Nydam \& Cifelli (2002) and Brizuela \& Albino (2010). Systematic arrangement follows Venczel \& Codrea (2015).

The fossils described here were collected in the limestone of Gruta do Urso cave, at Aurora do Tocantins $\left(12^{\circ} 35^{\prime} 0.08^{\prime \prime} \mathrm{S}\right.$ and $\left.46^{\circ} 30^{\prime} 58.39^{\prime \prime} \mathrm{W}\right)$, State of Tocantins, northern Brazil (Figure 1). The geological context of the study area is still poorly understood. The only available information is online notes of Companhia de Pesquisa de Recursos Minerais (CPRM) on the geology of the municipality report carbonate and terrigenous deposits of the Bambuí Group, which is Neoproterozoic in age (CPRM, 2006). The excavation in the cave was controlled in order to recognize stratigraphic aspects. Three stratigraphic levels were recognized as follows: (i) a bottom layer of the deposit is non-fossiliferous and yellowish; (ii) a middle layer is the fossiliferous level and composed of laminated reddish-grey loess-like sediment and a thickness of around 180 to $220 \mathrm{~mm}$; and (iii) a superficial carbonate cement

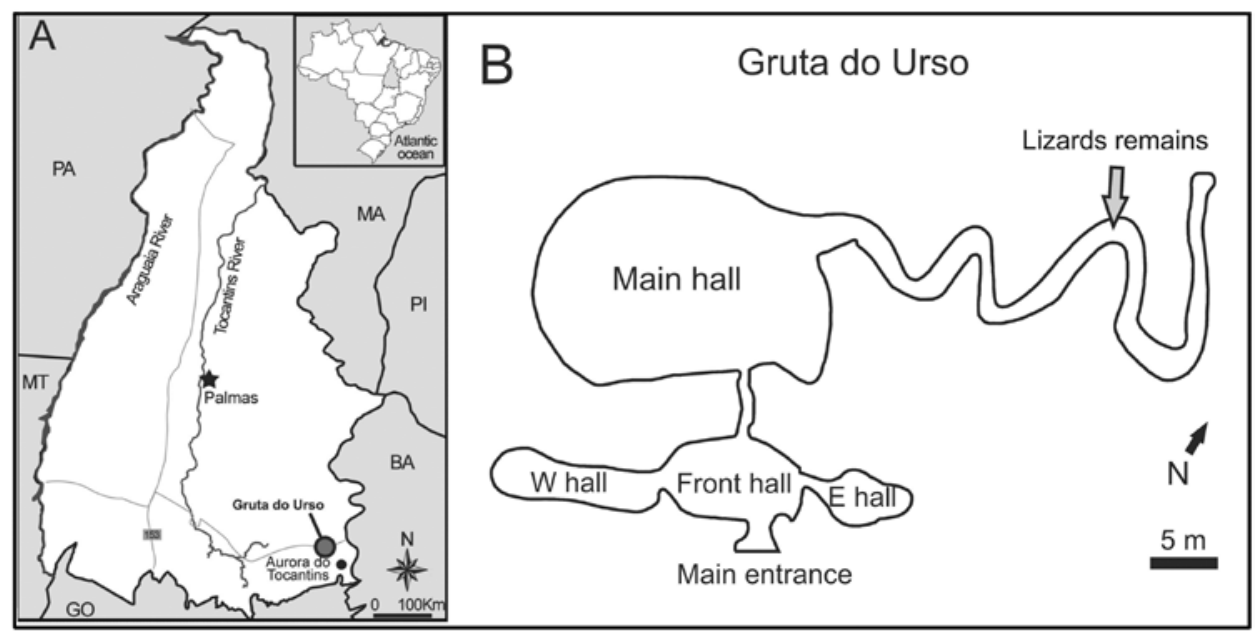

Figure 1. Location of Gruta do Urso. A, State of Tocantins, northern Brazil, showing its capital Palmas and its major rivers: Araguaia and Tocantins. The black circle denotes the municipality of Aurora do Tocantins, where Gruta do Urso is located (grey circle). B, schematic diagram of Gruta do Urso, and the specific site where the lizards remains were found. 
that covers the cave deposit, and represents the top of the fossil bearing layer. Based on the associated mammalian fauna, the armadillo genus Propraopus (Ensenadan-Lujanian) and the equid species Equus neogeus (Lujanian) (Cione \& Tonni, 1999), the teiid fossils are considered to be late Pleistocene in age (Maldonado et al., 2016).

\section{SYSTEMATIC PALEONTOLOGY}

Order SQUAMATA Oppel, 1811

Suborder SCLEROGLOSSA Estes et al., 1988

Infraorder SCINCOMORPHA Camp, 1923

Superfamily TEIOIDEA Estes et al., 1988

Family TEIIDAE Gray, 1827

Subfamily TEIINAE Gray, 1827

"Cnemidophorine"

Genus and species indet.

(Figures 2-3)

Referred specimen. UNIRIO-NM 0002, a complete left lower jaw.

Locality. Gruta do Urso, Aurora do Tocantins, southern State of Tocantins, northern region of Brazil $\left(12^{\circ} 35^{\prime} 0.08^{\prime \prime} \mathrm{S}\right.$; 46³0'58.39' W).
Description. UNIRIO-NM 0002 is a robust complete left lower jaw ( $\sim 2 \mathrm{~mm}$ of length). In general view the lower jaw is well preserved. The region between the dentary/ surangular/ angular contact is fragmented, and the anterior region of the splenial is lacking. The dentary is relatively long and dorsally concave. It is narrow on the anterior portion, expanding laterally toward the contact with the coronoid, angular, and surangular. Due to the poor preservation between these bones, their contact cannot be delimited. The anterior dentary region of the jaw is quite thin and low while the post-dentary region is more robust and high. Proportionally, the dentary is relatively large, composing at least half the total length of the lower jaw $(\sim 20.2 \mathrm{~mm})$. The lateral surface of the dentary is smooth, without ornamentation and with three oval mental foramina. In medial view, the dentary is markedly concave, being quite sharp anteriorly, and displays a shallow symphysis and a deep labial surface. The subdental shelf is located ventrally to the tooth bases, and is well developed for the full extent of the dentary, as observed in occlusal view. The dentary rises posteriorly toward its labial and lingual articulations with the coronoid. Meckel's groove is widely open all the way to the mandibular symphysis, which is thin and shows a slightly rugose articular surface, separated from the posterior portion of the dentary by a

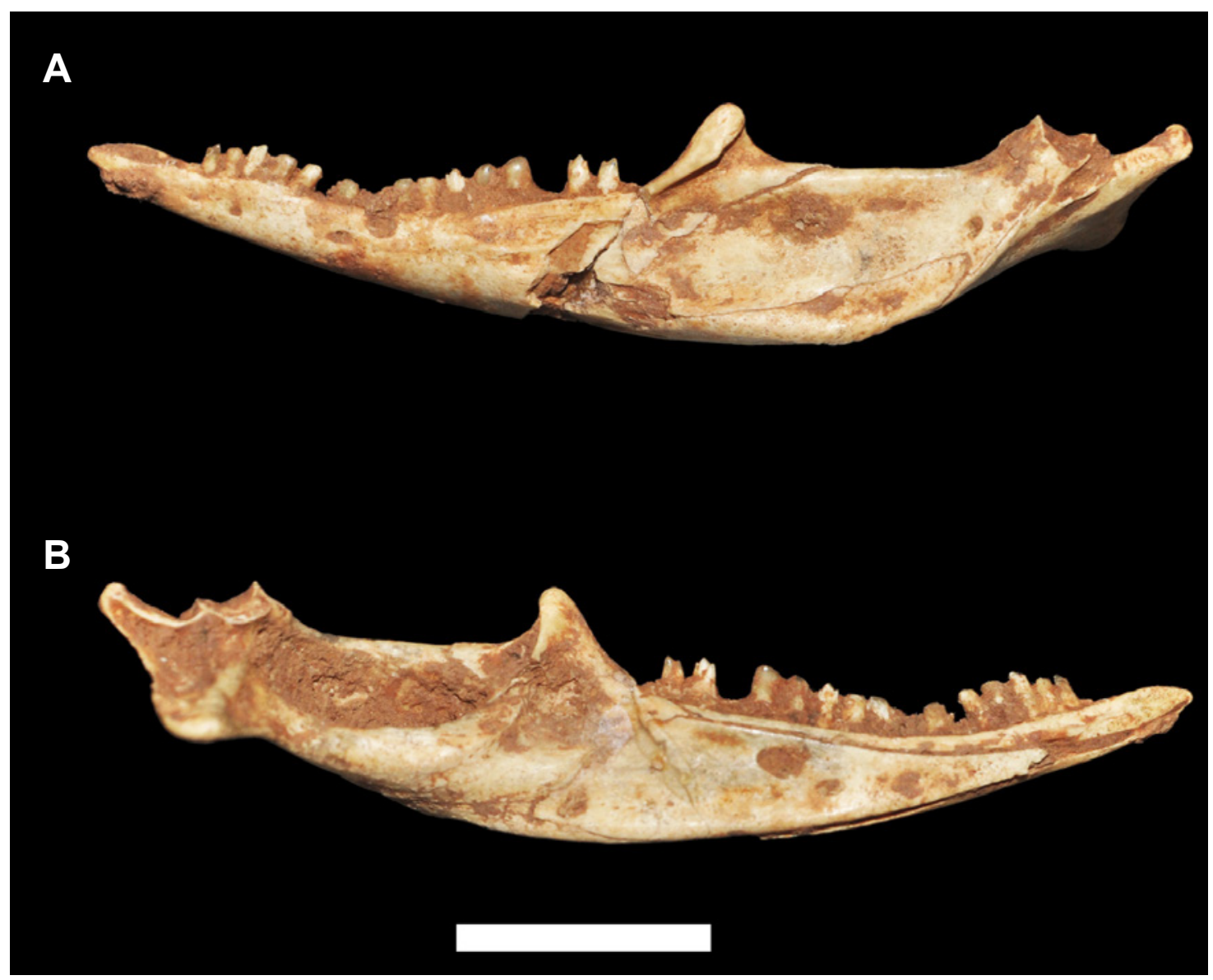

Figure 2. Complete left lower jaw (UNIRIO-NM 0002) attributed to an indeterminate "Cnemidophorine". In lateral (A) and medial (B) views. Scale bar $=10 \mathrm{~mm}$. 

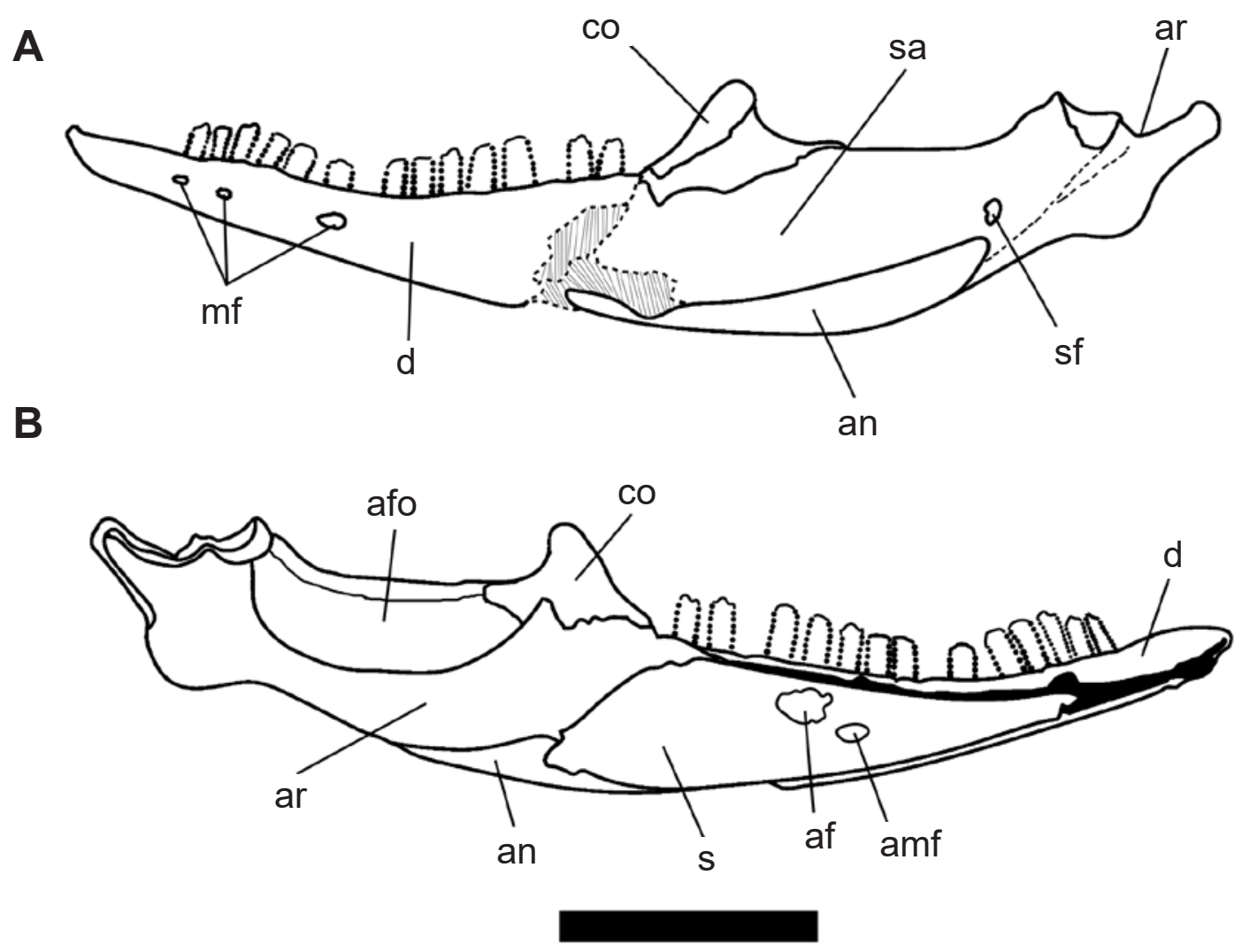

Figure 3. Schematic drawing of the complete left lower jaw of an indeterminate "Cnemidophorine" (UNIRION-NM 0002). In lateral (A) and medial (B) views. Abbreviations: af, alveolar foramina; afo, adductor fossae; amf, anterior mylohyoid foramina; an, angular; ar, articular; co, coronoid; d, dentary; mf, mental foramina; s, splenial; sa, surangular; sf, surangular foramina. Scale bar $=10 \mathrm{~mm}$.

short constriction. The splenial is elongated and gracile, extending posteriorly to the ventral region of the contact with the coronoid and dorsal to the angular. There are two lingual foramina, the anterior mylohyoid foramen and the alveolar foramen (Figure 2; Camolez \& Zaher, 2010). The anterior mylohyoid foramen is oval and smooth, whereas the alveolar foramen is larger and more irregular. The splenial is hypertrophied (Denton \& O'Neill, 1995; Camolez \& Zaher, 2010), with an anterior edge straight and thin, not reaching the mandibular symphysis. The dorsal process of the coronoid is inclined in an anterolateral to posteromedial direction, and has a rounded free edge (dorsal), with a long base, and a steeply inclined anterior edge. A narrow, but prominent crest begins from the posterior edge of the dorsal process, and extends on to the lateral surface of the dorsal and lateral edges, until it makes contact with the dentary. The anterolateral process is broken, however it is more or less vertically aligned with the anterior extremities of the angular and surangular bones. The anteromedial process surrounds the posterior edge of the dentary ventrally. The posteromedial process (posteriorly displaced due to breakage) is short and posteriorly inclined and forms the anterior portion of the ventral edge of the mandibular foramen. The surangular represents a large portion of the post-dentary region; it is predominantly flattened, smooth and located ventrally to the dorsal process of the coronoid. On the posterior region, dorsal to the suture with the angular, there is a surangular foramen. The angular forms a distinct concave bone that supports most of the ventrolateral surface of the lower jaw. The angular shows a slender anterior portion, and its thickness posteriorly, with a prominent crest on the lateral surface, is a characteristic usually observed in Teiinae (Camolez \& Zaher, 2010). A posterior mylohyoid foramen was not observed. The articular/retroarticular complex process is located posteriorly to the adductor fossa and comprises most of the medial and lateral postcoronoid surfaces of the lower jaw. Ventral to the adductor fossa, the articular has a round shape, characterizing the angular process, which extends from the coronoid to the retroarticular process (seen in lateral view). The retroarticular process is located posterior to the glenoid fossa and is posterolaterally oriented in occlusal view. Dentition: tooth implantation is subpleurodont with a well-developed sulcus dentalis, and attachment is predominantly basal, with scarce basal deposits of cementum and weakly visible interdental septa (Brizuela, 2010). The dentition is heterodont and there are at least thirteen teeth preserved in nineteen tooth positions (due to the impregnation of $\mathrm{CaCo}_{3}$ we are uncertain how many tooth positions are present). The three anterior-most teeth display two cusps, while the fourth to eighth teeth are unicuspid. More posterior teeth vary in cusp morphology, and are relatively robust and larger than the mesial teeth. The ninth tooth is tricuspid, with two accessory cusps, a mesial and a distal one, smaller than the main central cusp. 
The tenth and eleventh teeth do not exhibit accessory cusps, and they show an increase in tooth size and interdental spacing. The last two distal teeth are tricuspid, resembling the tooth morphology of the ninth tooth, and are interpreted as replacement teeth.

Comments. Brazilian Quaternary Teiinae fossils are known from Bahia, Goiás, Minas Gerais, Pernambuco, and Ceará states, mainly represented by the genus "Ameiva" (Camolez \& Zaher, 2010; Hsiou et al., 2012; Ferreira et al., 2012). The specimen UNIRIO-NM 0002 shares with Teiidae the following features: heterodont dentition; presence of multicuspid teeth (bicuspidate and tricuspidate) with asymmetric bicuspid teeth and the trend to develop flattened molariform teeth posteriorly on the tooth row (Presch, 1974b; Estes, 1983). The material shares the Teiinae subpleurodont condition; a large anterior inferior alveolar foramen, posteriorly localized and small anterior mylohyoid foramen in the splenial; large splenial that expands posteriorly; lateral expansion of the prearticular, forming with surangular and angular a prominent adductor crest; anterior restriction of the Meckel's groove, which is anteriorly continuous under the symphysis (Estes, 1983; Brizuela, 2010; Camolez \& Zaher, 2010). Among the Teiinae genera, the fossil specimen differs from Dicrodon and Teius based on distinct dental morphology of these genera, specifically, the development of transverse bicuspid teeth from the sixth tooth on (see Presch, 1974b, fig. 3). This morphology is inconsistent with that observed in UNIRIO-NM 0002. The lower jaw length ( $\sim 2 \mathrm{~mm}$ of full length) of UNIRIO-NM 0002 together with the dentition morphology is clearly similar to that observed in "Ameiva" and "Cnemidophorus" (Brizuela, 2010; Hsiou et al., 2012; Parmley \& Bahn, 2012). Some observed features, such as the presence of the scarce basal deposit of cementum with weakly visible interdental septa, appear to be exclusive to the informal group called "Cnemidophorine" (Reeder et al., 2002; Giugliano et al., 2007; Brizuela, 2010) that traditionally includes the genera "Ameiva", "Cnemidophorus", Aspidoscelis and Kentropyx with a controversial systematic relationship. This group shows a great similarity in dentition morphology (Presch, 1974b). As a whole, the anterior teeth are isodont, while the distal teeth develop into bicuspidate and tricuspidate forms on the posterior region of the dentary (Presch, 1974b). Despite the similar tooth morphology, the genus Kentropyx presents a pleurodont condition (Presch, 1974b), and generally shows similar accessory cusp heights on tricuspid teeth (Camolez \& Zaher, 2010), features that are distinct from the fossil specimen. Between "Cnemidophorus" and "Ameiva" there are subtle differences in the development of bicuspidate teeth to tricuspidate. In both genera the presence of tricuspidate teeth are predominantly located on the distal region of the dentary, which illustrates similarity between these genera (Presch, 1974b). However, the distribution and the amount of biconodont and triconodont teeth in the dentary, could help to identify the genus: Ameiva usually has more than 10 tricuspid teeth ( $\pm 50 \%$ of tooth row), whereas in Cnemidophorus the number of asymmetrical bicuspid teeth is higher than tricuspid ones (Parmley \& Bahn, 2012). Additionally, the tricuspid teeth in some species of Cnemidophorus are completely absent or with only one posterior most occurrence (Presch, 1974b). In this way, UNIRIO-NM 0002 may represent a Cnemidophorus due the large number of asymmetrical bicuspid teeth, and only two tricuspid teeth on the anterior portion of the dentary. However, this information alone does not isolate Cnemidophorus as the only possibility. Thus, we prefer to use a more conservative approach in our taxonomic attribution, and point out the need for more extensive comparative collections, and detailed osteological studies to support lower taxonomic assignments.

\section{Subfamily TUPINAMBINAE Bonaparte, 1831}

Tupinambis Daudin, 1802

Tupinambis sp.

(Figure 4)

Referred specimen. UNIRIO-NM 0003, an incomplete right dentary.

Locality. Gruta do Urso, municipality of Aurora do Tocantins, southern State of Tocantins, northern region of Brazil (12³5'0.08”'S; 4630'58.39”'W).

Description. UNIRIO-NM 0003 is a fragmentary right dentary with well-preserved dentition. The dentary lacks most of the posterior and ventral surfaces, as well as the anterior tip. There are eight teeth preserved, and at least two empty anterior tooth positions. Tooth morphology presents features observed by Brizuela \& Albino (2010) in Tupinambis merianae. All the teeth exhibit some degree of tooth wear. The first four teeth preserved are unicuspid, large, robust, and distally inclined, with slight grooves on the enamel. The third and fourth teeth were larger and robust (size length of $\sim 3.3 \mathrm{~mm}$ and $\sim 3.2 \mathrm{~mm}$ respectively) with evident enamel grooves. The fourth tooth is low and larger, with increase of the occlusal surface due to decreased buccolingual compression. This feature is interpreted as a tendency to molariformity (Brizuela \& Albino, 2010). The last four teeth present strong wear facets, which are interpreted as molariform. The crowns are low and buccolingually compressed. There is only one dominant cuspid on the seventh tooth, with a well-defined and slender mesodistal crest, which could indicate that this was a robust blunt tricuspid tooth (sensu Brizuela \& Albino, 2010).

Comments. Individuals of the genus Tupinambis includes some of the largest living lizards of the Americas and the largest Tupinambinae teiids. The natural occurrence of the genus is confined to South America (east of the Andes, and from northern Venezuela to the north of Patagonia (Peters \& Donoso-Barros, 1970; Presch, 1973; Cei \& Scolaro, 1982; Ávila-Pires, 1995; Herrera \& Robinson, 2000; Péres-Júnior, 2003). The described fossil (UNIRIO-NM 0003) shares with Teiidae the heterodont condition with differentiation along the tooth row, and the development of flattened 


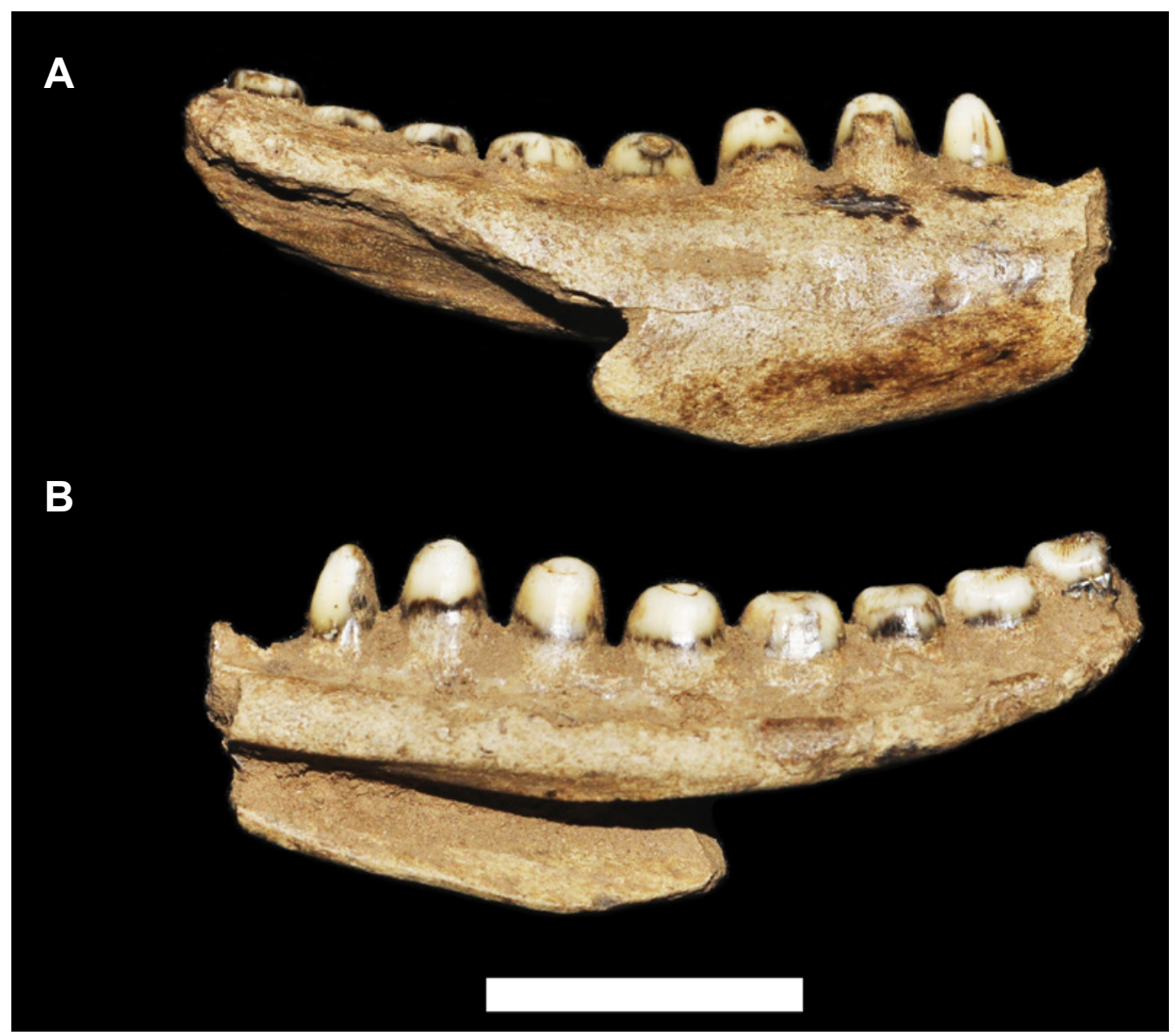

Figure 4. Partial right dentary attributed to Tupinambis sp. (UNIRIO-NM 0003). In labial (A) and lingual (B) views. Scale bar $=10 \mathrm{~mm}$.

molariform teeth (Presch, 1974b; Estes, 1983). Within Tupinambinae, UNIRIO-NM 003 shares the following features: subpleurodont dentition, a basal attachment with extensive deposits of cementum and a well-developed sulcus dentalis (Nydam et al., 2007). Among the Tupinanbinae genera, UNIRIO- NM 003 differs from the Crocodilurus and Callopistes due to the occurrence of strongly recurved and sharply pointed isodont teeth on the lower jaw present in these genera (Presch, 1974b; Evers-Junior \& Soares, 2007), characteristics that are distinct from the blunt almost vertical teeth, present on UNIRIO-NM 0003. The genus Dracaena shows a completely distinct teeth pattern from the other Tupinambinae, with the anterior-most teeth blunt and isodont, and the remaining posterior teeth developed into "crushing plates" due to anteroposterior expansion (Presch, 1974b). Mature individuals of Tupinambis, usually show strongly recurved isodont anterior teeth and the presence of isodont posterior blunt teeth (Presch, 1974b; Brizuela \& Albino, 2010). According to some authors (e.g. Presch, 1974b; Brizuela \& Albino, 2010; Barberena et al., 1970; Presch, 1974b; Estes \& Williams, 1984; Dessem, 1985; Montero et al., 2004) juvenile specimens of Tupinambis show a distinct dentition pattern, which is usually characterized by the presence of isodont anterior teeth (the first five teeth) and the more posterior teeth (generally the 6th to 14th) are tricuspidate. Although the specimen UNIRIO-NM 0003 is an incomplete right dentary, the dental features observed are consistent with Tupinambis species and ontogenetic variation. The described specimen is especially similar to the extant species T. merianae (see Brizuela \& Albino, 2010). According to the species list by the Sociedade Brasileira de Herpetologia (SBH, Brazilian Herpetological Society) (Bérnils \& Costa, 2012), seven species are recognized: T. teguixin Linnaeus, 1758; T. rufescens Günther, 1817; T. merianae Duméril \& Bibron, 1839; T. duseni Lonnberg, 1910; T. longilineus Ávila-Pires, 1995; T. quadrilineatus Manzani \& Abe, 1997; and T. palustris Manzani \& Abe, 2002 (validity contested by Péres-Júnior, 2003). Due to this diversity, and the lack of comparative dental studies of all Tupinambis species, we avoid a specific attribution to UNIRIO-NM 003, recognizing it only as Tupinambis sp.

Recently, Harvey et al. (2012) proposed the paraphyly of Tupinambis, and they erected a new genus combination: Salvator, which includes the more southern distributed S. merianae, S. duseni, and S. rufescens; while the Tupinambis species are represented by the more northern $T$. longilineus, T. teguixin, T. palustris, and T. quadrilineatus. It is noteworthy that the Harvey et al. (2012) study is not based on osteological information, which is needed for distinguishing and understanding the phylogenetic relationship of the fossil and extant terminal taxa of the Teiidae (e.g. Estes et al., 1988; Nydam \& Cifelli, 2002; Nydam et al., 2007; Conrad, 2008). 
Thus, due to the vast knowledge of the osteological anatomy, as well as the paleontological data applied for this family in several other morphological studies, the new taxonomic and systematic approach proposed by Harvey et al. (2012) is not followed here.

\section{DISCUSSION}

According to Hsiou et al. (2013) the squamate assemblage from Aurora do Tocantins region, is represented so far by the boid snake Eunectes murinus (Linnaeus, 1758); and by the two teiid lizards described here, "cnemidophorine" indet. and Tupinambis sp. Currently, Tupinambis and "cnemidophorines" (such as "Ameiva" and "Cnemidophorus") are part of the squamate community in the Aurora do Tocantins region. Most species of these two lizard genera have a wide geographic distribution, and can be considered generalists and opportunistic in terms of ecological and physiological requirements, occupying both open and forested areas, and wet or dry environments (see Vitt \& Colli, 1994; Ávila-Pires, 1995; Colli \& Paiva, 1997; Andrade et al., 2004; Winck et al., 2011). Thus, the presence of these lizards in the fossil assemblage of Aurora do Tocantins do not provide data on a specific environmental condition.

According to Cione \& Tonni $(1999,2005)$ the northern region of South America was open and dry during the Lujanian. Three species from Gruta do Urso, Catagonus stenocephalus (Lund in Reinhardt, 1880), Equus neogeus Lund, 1840 and Propraopus sulcatus (Lund 1838), may suggest an open and dry environment for the region during the Late Pleistocene (Avilla et al., 2013; Castro et al., 2013; Rodrigues et al., 2014). The paleoecological implications of the vertebrate record from Gruta do Urso cave remains unclear. Some associated fossil taxa, like the anaconda, capybara, and alligatorid, indicate permanent water habitats, while some mammals of the fossil assemblage are more indicative of dry and open areas. The arguments of Bernardes (2013) corroborate a drier and warmer climate recognized by stable isotopic analyses of Panthera onca (Linnaeus, 1758) and Arctotherium wingei Ameghino, 1902 fossils from the same deposit and strata at Gruta do Urso. The inferred dry climate interpretation is quite different from the current humid Cerrado where the caves of the region of Aurora do Tocantins occur. Thus, the climate may have changed to a more consistent humid environment during the Holocene. Considering the extant and fossil teids noted here, we cannot imply any possible influence of local climatic change. For such interpretations to occur we need specific identifications and radiometric dates on the fossils.

\section{CONCLUSIONS}

The lizard fossil record of Aurora do Tocantins is represented by the family Teiidae, with two specimens recognized as an indeterminate "cnemidophorine" and Tupinambis. These recovered remains exemplify the difficulty in identifying squamates to specific levels based on fragmented material. This difficulty results from a lack of autapomorphic characters and limited studies regarding the osteological features of extant lizards, especially within the "Cnemidophorinae" group (Bell et al., 2010). A review of osteological features searching for autapomorphic cranial characters in extant teiids could refine identifications. However, an extensive comparative collection is needed. In order to avoid misidentification we assign these new records to generic level. In addition, we contribute new knowledge to the herpetofaunal diversity during the Quaternary of northern Brazil and provide insights for further studies on this fossiliferous site.

\section{ACKNOWLEDGMENTS}

The expeditions to Aurora do Tocantins and the curatorial procedures of the collected material were financially supported by the Conselho Nacional de Desenvolvimento Científico e Tecnológico (CNPq) in two projects: (i) the $\mathrm{MCT} / \mathrm{CNPq} \mathrm{n}^{\circ} 32 / 2010$ - Fortalecimento da Paleontologia Nacional/Edital 32/2010 - Faixa B, process n ${ }^{\circ} 401812 / 2010-3$; and (ii) Apoio a Projetos de Pesquisa/Chamada MCTI/ CNPq No 23/2011 - Apoio Técnico para Fortalecimento da Paleontologia Nacional, process $n^{\circ} 552975 / 2011-7$. ASH wishes to thank the financial support provided by Fundação de Amparo à Pesquisa de São Paulo (FAPESP, process $n^{\circ}$ 2011/14080-0), SYOA wishes to thank the financial support provided by Coordenação de Aperfeiçoamento de Pessoal de Nível Superior (CAPES), and BWS thanks the Office of Research and Sponsored Programs and the Don Sundquist Center of Excellence in Paleontology at East Tennessee State University for travel funding. Fundação Carlos Chagas Filho de Amparo à Pesquisa do Estado do Rio de Janeiro (FAPERJ) provided Postdoctoral Fellowship grant to GRW (Processes n. E-26/101.237/2013 and E-26/101.267/2013) and a researcher scholarship to LSA on the program "Jovem Cientista do Nosso Estado" E-25/2014.

\section{REFERENCES}

Abdala, V. \& Moro, S. 2003. A cladistic analysis of ten lizard families (Reptilia: Squamata) based on cranial musculature. Russian Journal of Herpetology, 10:53-78.

Albino, A.M. 1996. The South American fossil Squamata (Reptilia: Lepidosauria). In: G. Arratia (ed.) Contributions of Southern South America to Vertebrate Paleontology, München, Münchner Geowissenchaftliche Abhandlungen, p. 185-201 (Geologie und Paläontologie 30).

Albino, A.M. 2001. Reptiles. In: D.L. Mazzanti \& C.A. Quintana (eds.) Cueva Tixi: cazadores y recolectores de las sierras de Tandilla Oriental, Universidad Nacional de Mar del Plata, p. 65-74.

Albino, A.M. 2005. A Late Quaternary lizard assemblage from the Southern Pampean Region of Argentina. Journal of Vertebrate Paleontology, 25:185-191. doi:10.1671/02724634(2005)025[0185:ALQLAF]2.0.CO;2

Albino, A.M.; Brizuela, S. \& Montalvo, C.L. 2006. New Tupinambis remains from the Late Miocene of Argentina and a review of the South American Miocene teids. Journal of Herpetology, 40:206-213. doi:10.1670/44-05A.1 
Albino, A.M.; Montalvo, C. \& Brizuela, S. 2013. New records of squamates from the Upper Miocene of South America. Journal of Herpetology, 47:590-598. doi:10.1670/12-109

Albino, A.M.; Tomassini, R. \& Brizuela, S. 2009. Presencia del lagarto teido Tupinambis en la Formación Monte Hermoso de Farola Monte Hermoso, sur de la provincia de Buenos Aires (Argentina). Ameghiniana, 46:177-187.

Andrade, D.O.V.; Sanders, C.; Milsom, W. K. \& Abe, A.S. 2004. Overwintering integulizards. In: B.M. Barnes \& H.V. Carey (eds.) Life in the old: evolution, mechanisms, adaptation, and application, Institut of Arctic Biology, p. 339-348.

Avilla, L.S.; Muller, L.; Gasparini, G.M.; Soibelzon, L.; Absolon, B.; Pego, F.B.; Silva, R.C.; Kinoshita, A.; Figueiredo, A.M.G. \& Baffa, O. 2013. The northernmost Record of Catagonus stenocephalus (Lund in Reinhardt, 1880) (Mammalia, Cetartiodactyla) and its palaeoenvironmental and palaeobiogeographical significance. Journal of South America Earth Sciences, 42:39-46. doi:10.1016/j.jsames.2012.10.001

Ávila-Pires, T.C.S. 1995. Lizards of Brazilian Amazonia (Reptilia: Squamata). Leiden, Zoologische Verhandelingen, 299:1-176.

Barberena, M.; Gomes, N. \& Sanchotene, L. 1970. Osteologia craniana de Tupinambis teguixin. Publicação Especial da Escola de Geologia da UFRGS, 21:1-32.

Barros-Barreto, C.N.G.; De Blasis, P.D.; Dias Neto, C.M.; Karmann, I.; Lino, C.F. \& Robrahn, E.M. 1982. Abismo Ponta de Flecha: um projeto arqueológico, paleontológico e geológico no médio curso de Ribeira de Iguape, São Paulo. Revista de Pré-História, 3:195-215.

Bell, C.J.; Gauthier, J.A. \& Bever, G.S. 2010. Covert biases, circularity, and apomorphies: a critical look at the North American Quaternary Herpetofaunal Stability Hypothesis. Quaternary International, 217:30-36. doi:10.1016/j.quaint.2009.08.009

Bernardes, C. 2013. Paleoecologia dos grandes carnívoros (Carnivora: Mammalia) do Quaternário do Brasil. Programa de Pós-Graduação em Ciências Biológicas,Universidade Federal do Estado do Rio de Janeiro, M.Sc. thesis, 85 p.

Bérnils, R.S. \& Costa, H.C. 2012. Répteis brasileiros: Lista de espécies. Version 2012.2. Available at http://www. sbherpetologia.org.br/;c accessed in 05/09/2013.

Brizuela, S. 2010. Los lagartos continentales fósiles de la Argentina (excepto Iguania). Facultad de Ciencias Naturales y Museo, Universidad Nacional de La Plata, Tese de Doutorado, 422 p.

Brizuela, S. \& Albino, A.M. 2004. The earliest Tupinambis teiid from South America and its paleoenvironmental significance. Journal of Herpetology, 38:113-119. doi:10.1670/131-03A

Brizuela, S. \& Albino, A.M. 2008a. Re-evaluation of the type material of "Diasemosaurus occidentalis" Ameghino and "Dibolosodon typicus" Ameghino (Squamata: Teiidae) from the Miocene of Argentina. Journal of Vertebrate Paleontology, 28:253-257. doi:10.1671/0272-4634(2008)28[253:ROTTMO]2.0.CO;2

Brizuela, S. \& Albino, A.M. 2008b. Tupinambine teids from the middle Miocene of northwestern Patagonia (Argentina). AmphibiaReptilia, 29:425-431. doi:10.1163/156853808785112110

Brizuela, S. \& Albino, A.M. 2010. Variaciones dentarias en Tupinambis merianae (Squamata: Teiidae). Cuadernos de Herpetología, 24:5-16.

Brizuela, S. \& Albino, A.M. 2012a. The teiid lizard Tupinambis in the Miocene-Pliocene of Córdoba and Entre Ríos provinces (Argentina). Ameghiniana, 49:262-266. doi:10.5710/AMGH. v49i2(415)

Brizuela, S. \& Albino, A.M. 2012b. Los reptiles escamosos del Plioceno de la costa atlántica entre Mar del Plata y Miramar, provincia de Buenos Aires, Argentina. Revista del Museo Argentino de Ciencias Naturales, Nueva serie, 14:47-56.

Brizuela, S. \& Albino, A.M. 2015. First Tupinambinae teiid (Squamata, Teiidae) from the Palaeogene of South America. Historical Biology, 28:571-581. doi:10.1080/08912963.2014.993629

Camolez, T. \& Zaher, H. 2010. Levantamento, identificação e descrição da fauna de Squamata do Quaternário brasileiro (Lepidosauria). Arquivos de Zoologia, 41:1-96. doi:10.11606/ issn.2176-7793.v41i1p1-96

Castro, M.C.; Avilla, L.S.; Freitas, M.L. \& Carlini, A.A. 2013. The armadillo Propraopus sulcatus (Mammalia: Xenarthra) from the late Quaternary of northern Brazil and a revised synonymy with Propraopus grandis. Quaternary International, 317:80-87. doi:10.1016/j.quaint.2013.04.032

Cei, J.M. \& Scolaro, J.A. 1982. A population of Tupinambis from northern Patagonia, South of the Río Negro, Argentina. Herpetologica Review, 13:26.

Cione, A.L. \& Tonni, E.P. 1999. Biostratigraphy and chronological scale of upper-most Cenozoic in the Pampean area. In: J. Rabassa \& M. Salemme (eds.) Quaternary of South America and Antarctic Peninsula, A.A. Balkema Publishers, p. 22-51.

Cione, A.L. \& Tonni, E.P. 2005. Bioestratigrafía basada en mamíferos del Cenozoico superior de la provincia de Buenos Aires, Argentina. In: R.E. De Barrio; R.O. Etcheverry; M.F. Caballé \& E. Llambias (eds.) Geología y Recursos Minerales de la Provincia de Buenos Aires, Relatório del XVI Congreso geológico Argentino, Quick Press, p. 183-200.

Colli, G.R. \& Paiva, M.S. 1997. Estratégias de forrageamento e termorregulaçãoem lagartos do Cerrado e Savanas Amazônicas. In: L.L. Leite, \& C.H. Saito (eds.) Contribuição ao Conhecimento Ecológico do Cerrado, Universidade de Brasília, p. 224-231.

Conrad, J.L. 2008. Phylogeny and systematics of Squamata (Reptilia) based on morphology. Bulletin of the American Museum of Natural History, 310:1-182. doi:10.1206/310.1

CPRM. 2006. Rochas Carbonáticas do Grupo Bambuí na região Nordeste do Estado de Goiás. Available at http://www.cprm.gov. br/publique/cgi/cgilua.exe/sys/start.htm?infoid=261\&sid=32; accessed in 05/09/2010.

Denton, R.K. \& O’Neill, R.C. 1995. Prototeius stageri gen. et sp. nov., a new teiid lizard from the Upper Cretaceous Marshalltown Formation of New Jersey, with a preliminary phylogenetic revision of the Teiidae. Journal of Vertebrate Paleontology, 15:235-253. doi:10.1080/02724634.1995.10011227

Dessem, D. 1985. Ontogenetic changes in the dentition and diet of Tupinambis (Lacertilia: Teiidae). Copeia, 1985:245-247. doi: $10.2307 / 1444823$

Estes, R. 1983. Sauria terrestria, Amphisbaenia. In: P. Wellnhofer (ed.) Handbuch der Paleoherpetologie, Gustav Fisher Verlag, p. 1-249.

Estes, R.; Queiroz, K. \& Gauthier, J. 1988. Phylogenetic relationships within Squamata. In: R. Estes \& G. Pregill (eds.) Phylogenetic relationships of the lizard families, Stanford University Press, p. 119-281.

Estes, R. \& Williams, E.E. 1984. Ontogenetic variation in the molariform teeth of lizards. Journal of Vertebrate Paleontology, 4:96-107. doi:10.1080/02724634.1984.10011989

Evers-Junior, P.R. \& Soares, M. 2007. Descrição do crânio de Crocodilurus amazonicus Spix, 1825 (Squamata, Teiidae). Arquivos do Museu Nacional, 65:49-57.

Faure, M., Guérin, C., Parenti, F. 1999. Découverte d'une mégafaune Holocène à la Toca do Serrote do Artur (aire archéologique de São Raimundo Nonato, Piauí, Brésil). Comptes Rendus de l'Académie des Sciences Series II Sciences de La Terre et dês planètes, 329:443-448. doi:10.1016/S1251-8050(00)80069-5 
Ferreira, D.; Silva, A.K.B.; Matos, C.H.C.; Hadler, P. \& Hsiou, A.S. 2012. Assembleia holocênica de vertebrados de pequeno porte do Sítio Alcobaça, Estado de Pernambuco, Brasil. Revista Brasileira de Paleontologia, 15:359-370. doi:10.4072/rbp.2012.3.11

Gauthier, J.A.; Kearney, M.; Maisano, J.A.; Rieppel, O. \& Behlke, A.D.B. 2012. Assembling the Squamate Tree of Life: Perspectives from the Phenotype and the Fossil Record. Bulletin of Peabody Museum of Natural History, 53:1-306. doi:10.3374/014.053.0101

Giugliano, L.G.; Collevatti, R.G. \& Colli, G.R. 2007. Molecular dating and phylogenetic relationships among Teiidae (Squamata) inferred by molecular and morphological data. Molecular Phylogenetics and Evolution, 45:168-179. doi:10.1016/j. ympev.2007.05.017

Goicoechea, N.; Frost, D.R.; Riva, I.D.L.; Pellegrino, K.C.M.; Sites Jr., J.; Rodrigues, M.T. \& Padial, J.M. 2016. Molecular systematics of teioid lizards (Teioidea/ Gymnophthalmoidea: Squamata) based on the analysis of 48 loci under tree-alignment and similarity alignment. Cladistics, 2016: 1-48. doi:10.1111/cla.12150

Guérin, C. 1991. La faune de vertébr'rs du Pléistocène supérieur de l'aire archéologique de São Raimundo Nonato (Piauí, Brésil). Comptes Rendus de l'Académie des Sciences Series II Sciences de La Terre et dês planètes, 312:567-572.

Guérin, C.; Curvello, M.A.; Faure, M.; Hugueney, M. \& MourerChauviré, C. 1993. La faune pléistocène du Piauí (Nordeste du Brésil): implications paléoécologiques et biochronologiques. Quaternaria Nova, 3:303-341.

Harvey, M.B.; Ugueto, G.N. \& Gutberlet-Jr. R.L. 2012. Review of teiid morphology with a revised taxonomy and phylogeny of the Teiidae (Lepidosauria: Squamata). Zootaxa, 3459:1-156. doi:10.7934/P759

Herrera, E.A. \& Robinson, M.D. 2000. Reproductive and fat body cycles of the tegu lizard, Tupinambisteguixin, in the Llanos of Venezuela. Journal of Herpetology, 34:598-601. doi: $10.2307 / 1565277$

Hsiou, A.S. 2007. A new Teiidae species (Squamata, Scincomorpha) from the Late Pleistocene of Rio Grande do Sul State, Brazil. Revista Brasileira de Paleontologia, 10:181-194.

Hsiou, A.S.; Albino, A.M. \& Ferigolo, J. 2009. First lizard remains (Teiidae) from the Miocene of Brazil (Solimões Formation). Revista Brasileira de Paleontologia, 12:225-230. doi:10.4072/rbp.2009.3.05

Hsiou, A.S.; Oliveira, P.V.; Ximenes, C.L. \& Viana, M.S.S. 2012. Lizards and snakes (Lepidosauria, Squamata) from the Late Quaternary of the State of Ceará in northeastern Brazil. Journal of Cave and Karst Studies, 74:262-270. doi:10.4311/2011PA0239

Hsiou, A.S.; Winck, G.; Schubert, B.W. \& Avilla, L.S. 2013. On the presence of Eunectes murinus (Squamata, Serpentes) from the Late Pleistocene of northern Brazil. Revista Brasileira de Paleontologia, 16:77-82. doi:10.4072/rbp.2013.1.06

Krause, L. 1985. Fossil record of the family Teiidae. Notes on paleobiogeography, current distribution, and habits of macroteids (Sauria, Scincomorpha, Teiidae). Studies on Neotropical Fauna and Environment, 20:175-188.

Lund, M. 1840. Nouvelles recherché sur la faune fossile du Brésil. Annales des sciences naturelles: zoologie et biologie animale, 13:310-319.

Maldonado, V.; Monteiro, L.G.P.; Rotti, A.; Pereira, C.; AraújoJúnior, H.I. \& Avilla, L.S. 2016. Taphonomic aspects of Deer (Mammalia, Cetartiodactyla, Cervidae) remains from a Quaternary cave deposit in Northern Brazil. Journal of Sedimentary Environments, 1:234-248. doi:10.12957/ jse.2016.23026
Montero, R.; Abdala, V.; Moro, S. \& Gallardo, G. 2004. Atlas de Tupinambis rufescens (Squamata: Teiidae). Anatomía externa, osteología y bibliografía. Cuadernos de Herpetología, 18:17-32.

Moro, S. \& Abdala, V. 2000. Cladistic analysis of Teiidae (Squamata) based on cranial mycological characters. Russian Journal of Herpetology, 7:87-102.

Nydam, R.L. \& Cifelli, R.L. 2002. A new teiid from the Cedar Mountain Formation (Albian-Cenomanian boundary) of Utah. Journal of Vertebrate Paleontology, 22:276-285. doi:10.1671/0272-4634(2002)022[0276:ANTLFT]2.0.CO;2

Nydam, R.L.; Eaton, J.G. \& Sankey, J. 2007. New taxa of transversely-toothed lizards (Squamata: Scincomorpha) and new information on the evolutionary history of "teids". Journal of Paleontology, 81:538-549. doi:10.1666/03097.1

Paula-Couto, C. 1978. Mamíferos fósseis do Pleistoceno do Espírito Santo. Anais da Academia Brasileira de Ciência, 50:365-379.

Parmley, D. \& Bahn, J.R. 2012. Late Pleistocene Lizards from Fowlkes Cave, Culberson County, Texas. The Southwestern Naturalist, 57:435-441. doi:10.1894/0038-4909-57.4.435

Péres-Júnior, A.K. 2003. Sistemática e conservação de lagartos do gênero Tupinambis (Squamata, Teiidae). Universidade de Brasília, Ph.D. thesis, 192 p.

Peters, J.A. \& Donoso-Barros, R. 1970. Catalogue of the Neotropical Squamata: Part II, Lizards and Amphisbaenians. Washington, Smithsonian Institution Press, 293 p.

Pough, F.H.; Andrews, R.M.; Cadle, J.E.; Crump, M.L.; Savitzky, A.H. \& Wells, K.D. 1998. Herpetology. New Jersey, Prentice Hall, 577 p.

Presch, W. 1973. A review of the tegus, lizard genus Tupinambis (Sauria: Teiidae) from South America. Copeia, 1973:740-746. doi: $10.2307 / 1443074$

Presch, W. 1974a. Evolutionary relationships and biogeography of the macroteiid lizards (Family Teiidae, Subfamily Teiinae). Bulletin of the Southern California Academy of Sciences, 73:23-32.

Presch, W. 1974b. A survey of the dentition of the macroteiid lizards (Teiidae: Lacertilia). Herpetologica, 30:344-349.

Presch, W. 1980. Evolutionary history of the South American microteiid lizards (Teiidae: Gymnophthalminae). Copeia, 1980:36-56. doi:10.2307/1444132

Presch, W. 1983. The lizard family Teiidae: is it a monophyletic group? Zoological Journal of the Linnean Society, 77:189-197. doi:10.1111/j.10963642.1983.tb00529.x

Pujos, F.; Albino, A.M.; Baby, P. \& Guyot, J.L. 2009. Presence of the extinct lizard Paradracaena (Teiidae) in the Middle Miocene of the Peruvian Amazonic. Journal of Vertebrate Paleontology, 29:594-598. doi:10.1671/039.029.0227

Reeder, T.W.; Charles, C.J. \& Dessauer, H.C. 2002. Phylogenetic relationships of whiptail lizards of the genus Cnemidophorus (Squamata: Teiidae): a test of monophyly, reevaluation of karyotypic evolution, and review of hybrid origins. American Museum Novitates, 3365:1-61. doi:10.1206/00030082(2002)365<0001:PROWLO>2.0.CO;2

Rodrigues, S.; Avilla, L. S.; Soibelzon L. \& Bernardes, C. 2014. Late Pleistocene carnivores (Carnivora: Mammalia) from a cave sedimentary deposit in northern Brazil. Anais da Academia Brasileira de Ciências, 86:1641-1655. doi:10.1590/00013765201420140314

Savage, J.M. 1966. The origins and history of the Central American herpetofauna. Copeia, 1966:719-766. doi:10.2307/1441404

Simões, T.R.; Caldwell, M.W.; Palci, A. \& Nydam, R.L. 2016. Giant taxon-character matrices: quality of character constructions remains critical regardless of size. Cladistics, 2016:1-22. doi:10.1111/cla.12163 
Sullivan, R.M. \& Estes, R. 1997. A reassessment of the fossil Tupinambinae. In: R.F. Kay; R.H. Madden; R.L. Cifelli \& J.J. Flynn (eds.) Vertebrate Paleontology in the Neotropics, Smithsonian Institution Press, p. 100-112.

Teixeira, R.D. 2003. Análise filogenética da família Teiidae (Squamata, Reptilia), a Ultra-estrutura de espermatozoide e a sua utilidade filogenética. Universidade Estadual de Campinas, Ph.D. thesis, $217 \mathrm{p}$.

Venczel, M. \& Codrea, V.A. 2015. A new teiid lizard from the Late Cretaceous of the Hateg Basin, Romania and its phylogenetic and palaeobiogeographical relationships. Journal of Systematic Palaeontology, 14:219-237. doi:10.1080/14772019.2015.1025869

Vitt, L.J. \& Colli, G.R. 1994. The geographical ecology of a neotropical lizard: Ameiva ameiva (Teiidae) in Brazil. Canadian Journal of Zoology, 72:1986-2008. doi:10.1139/z94-271

Winck, G.R.; Blanco, C.C. \& Cechin, S.Z. 2011. Population ecology of Tupinambis merianae (Squamata, Teiidae): homerange, activity and space use. Animal Biology, 61:493-510. doi:10.1163/157075511X597647

Received in November, 2015; accepted in July, 2016. 